\title{
Accumulative vs. Appreciative Expressions of Materialism: Revising Materialism in Light of Polish Simplifiers and New Materialism
}

\author{
Justyna Kramarczyk ${ }^{1}$ (D) Mathieu Alemany Oliver $^{2}$ (D)
}

Received: 29 March 2020 / Accepted: 21 September 2020 / Published online: 30 September 2020

(c) The Author(s) 2020

\begin{abstract}
At a time when it is critically important to preserve natural resources and reduce the amount of man-made pollution, this article explores other potentials for materialism in today's market economies. Based on a two-year ethnography in Poland, we learn from simplifiers who denounce current materialism — while remaining inside the market—about what materialism could potentially become (or already is). Our study shows that materialism can take on other less studied but more eco-friendly expressions. In particular, we highlight an alternate expression of materialism, which we call "appreciative materialism" (in contrast to "accumulative materialism"). Appreciative materialism still ascribes a great deal of importance to objects in the lives of consumers but does so through the voluntary non-possession and/or non-accumulation of these objects, as well as a caring ethics that extends to non-humans. These findings call not only for the refinement of scales to measure materialism but also for a revision of the role of materialism in our lives. They suggest that, in order to trigger more sustainable practices, policymakers and managers should put greater emphasis on appreciative materialism.
\end{abstract}

Keywords Appreciative materialism $\cdot$ New materialism $\cdot$ Voluntary simplicity $\cdot$ Caring ethics

\section{Introduction}

"An idea opposed to another idea is always the same idea, albeit affected by the negative sign. The more you oppose one another, the more you remain in the same framework of thought" (Serres and Latour 1990/1995, p. 81).

A central tenet of our consumerist cultural ideology is materialism. While materialism can reflect a deeper material culture in which the market provides the tools to construct a

Justyna Kramarczyk and Mathieu Alemany Oliver: Both authors contributed equally to this article, and are listed in reverse alphabetical order.

Mathieu Alemany Oliver

m.alemany-oliver@tbs-education.fr

Justyna Kramarczyk

justyna.kramarczyk@polsca.pan.pl

1 The Polish Science Contact Agency of the Polish Academy of Sciences, Brussels, Belgium

2 Social \& Innovation Marketing Lab, TBS Business School, Toulouse, France personal and social identity, as well as cultural appropriation (Miller 1987), it has long been a subject of criticism as it can also negatively affect consumers' quality of life, the environment, and consumer ethics (Burroughs and Rindfleisch 2002; Kilbourne and Pickett 2008; Muncy and Eastman 1998; Sirgy 1998). In response to the negative outcomes of materialism, some consumer movements such as less-ismore movements and environmental activism emerged in opposition to materialism and suggest alternate modes of consumption that depart from the consumerist ideology. In parallel, research has shown that while consumers can barely escape the market (Kozinets 2002), they can at least change it. For instance, recent developments in the ways consumers consume materiality through sharing or joint ownership (Bardhi and Eckhardt 2012; Belk 2010) demonstrate that the market is an institution whose social practices necessarily and constantly adapt to businesses and to consumers' moves (Dolbec and Fischer 2015; Humphreys 2010; Martin and Schouten 2014).

This context of criticism of materialism that we currently experience should invite us to discuss new and future relations to materiality (Scott et al. 2014). Indeed, one of the main dilemmas facing business ethics today is how to maintain profitable relationships with consumers 
while preserving the environment. Governments and businesses rely on market economies that, in turn, rely on the maintenance of high levels of consumption through a constant stimulation of desire. Moreover, many consumers are not ready to consume less in order to reach an ecologically sustainable global economy (Alexander and Ussher 2012; Pretty et al. 2007). How can business ethics deal with this seemingly impossible-to-solve dilemma? This question is particularly critical since climate change, as several reports published by the Intergovernmental Panel on Climate Change (IPCC) have made clear, will not wait three more decades for market economies to engage more comprehensively in an alternate and (much) more sustainable system.

With the aim of enriching the debate on alternate possible expressions of materialism and rooting it in the business ethics literature, we ask: What can we learn from consumer movements that denounce current materialism while remaining inside the market about what materialism could potentially become (or already is)? In other words, are the members of these movements socially constructing and practicing another expression of materialism, which the market could draw on for a more sustainable economy?

Using a two-year ethnography with 22 Polish simplifiers, we focus on the relationships that these simplifiers have with their possessions and with objects in general and how these relationships may have been shaped by simplifiers' collective history during the time of the Polish People's Republic (1947-1989). The findings underline a more sustainable expression of materialism, which we qualify as appreciative (vs. accumulative) in the sense that it still gives objects a central place in consumers' lives but through voluntary nonpossession and/or non-accumulation, as well as an extended ethics of caring for them and for matter in general. More broadly, this research enriches the literature on materialism and caring and invites public policymakers and managers to communicate about appreciative materialism and related lifestyles so as to trigger more sustainable consumption behaviors.

The rest of this paper is structured as follows: After presenting what materialism is and can be in an age where sustainability is required, we shed light on the possibility for an alternate expression of materialism as expressed in Polish voluntary simplicity. We present our ethnography with Polish simplifiers and then share two main findings that challenge the widely accepted equation, materialism $=a c c u$ mulation. More particularly, these two findings deal with participants' relations to the quantity, quality, and symbolism of their possessions; and the alternate status given to objects, as well as the extended ethics of caring resulting from this alternate status of objects. We follow-up on this presentation of findings with a discussion of appreciative materialism (vs. accumulative materialism), the possible consequences for the measurement of materialism, and appreciative materialism's relation to sustainability.

\section{What Else Materialism Can Be}

\section{(New) Materialism in an Age Where Sustainability is Required}

In this paper, materialism is defined as "the importance a consumer attaches to worldly possessions" (Belk 1984, p. 291). Materialism leads consumers to (1) put possessions at the center of their lives, (2) depend on possessions to give meaning to life and to perceive themselves as happy, and (3) rely on the quantity and quality of possessions to judge themselves and others (Belk 1984; Richins and Dawson 1992; Richins and Rudmin 1994). It is also possible for materialism to be reflected in the personality traits of envy, non-generosity, possessiveness, and preservation (i.e., holding onto objects associated with past events, experiences, or memories) (Ger and Belk 1996). Partly for this reason and despite attempts to make it a more neutral concept (Shrum et al. 2013), materialism has often been criticized for driving excessive consumption and revealing consumers' dark side (e.g., Davidson et al. 2019; Hirschman 1991; Mick 1996; Miller 1987). While it is still a central concept of our consumerist society, materialism can seem like a set of values damaging not only consumers' well-being but also society and the environment (Burroughs and Rindfleisch 2002; Long-Chuan and Chia-Ju 2010; Kilbourne and Pickett 2008). However, materialism is still what fuels the economy and, therefore, what maintains society (Brown and Kasser 2005; Kasser 2003).

In parallel, new materialism, which is a growing movement of philosophical thought, offers fresh perspectives on our relationship to materiality and extends Appadurai's (1986) view of a thing's social life and its different biographical moments (see, for instance, Appadurai's recent concept of mediant, which underscores the critical role of mediation in human and non-human connections: Appadurai 2015). New materialism overcomes the traditional dualism (and the prioritization and/or hierarchization it often implicitly involves) between materialism and idealism in human science - that is, the traditional opposition between matter being the ultimate reality and the mind being the ultimate reality, respectively. Instead, new materialism offers a monistic conception of reality (i.e., comprising a single element) in which human and non-human (including non-biological) objects are not in opposition to each other but interdependent and constitute a whole and ever-changing set of relations in flux. In this context, not only culture but matter, too, is alive and changing. Objects are no longer inert objects that humans breathe 
life into; they have their own existence and set of relations outside of human intervention and representation. In other words, new materialism invites a decentering of the human being so that things also have their history and proper existence outside of humans, even as they remain co-constitutive of each other (see Dolphijn and van der Tuin 2012; Kissmann and van Loon 2019 for a recent and fairly comprehensive picture of new materialism). New materialism can be found in several similar but different theories that have spread in academia, including assemblage theory (considered the foundational work for new materialism-Deleuze and Guattari 1980), actor-network theory (Latour 2005), practice theory (Bourdieu 1972), and, more recently, speculative materialism or object-oriented ontology (Harman 2011; Meillassoux 2007). In marketing, these theories have been used to make new assumptions about the agency of objects and how the materiality of objects shape practices (Canniford and Shankar 2013; Epp and Price 2010; Hoffman and Novak 2018; Scaraboto et al. 2016). In a different vein, recent marketing literature has stressed how some consumers are (re)connected to their body (an organic matter and material), which they want to see and feel as being alive, whether through art or pain (Scott et al. 2017; Roux and Belk 2019). While these articles do not draw on new materialism, they potentially illustrate a return to matter that some regard as an opportunity to engage in new ontological directions that would benefit sustainable projects (Benson 2019).

Following Kilbourne et al. (1997), Scott et al. (2014) underline the need for a macromarketing approach to sustainable consumption and suggest new materialism as a possible answer-by remaining a form of materialism and, therefore, providing the possibility for our capitalist system to endure. While anti-consumption and anti-materialism movements can only strengthen the idea of consumption and materialism (like any anti-movement), new materialism overcomes these antagonisms to liberate our relations to non-human objects and, thereby, provides an opportunity to reframe what sustainable materialism could be. According to Schlosberg and Coles (2016), more sustainable forms of materialism are already visible in market and consumer movements concerned with the ecological and fair flow of objects. This is the case, for example, in the domain of food (e.g., farmers' markets, community-supported agriculture, slow food movement, etc.), energy (e.g., community energy, transition cities, etc.), and, more generally, DIY communities. All these examples illustrate a decentering of humans and better account for the flow of materials in our society. Another example is the repair market, which meets the demand of no longer systematically throwing away objects that we have used without really being conscious of their existence and, therefore, without really taking the time to know their history and the resources they require.

\section{The Evolving Expression of Materialism}

Asking what else materialism can be makes it necessary to conceptualize materialism and the way it is expressed as evolving. While materialism is often understood as a set of personality traits (Belk 1984) or personal values (Richins and Dawson 1992) that underline rather stable personal characteristics, personal traits and values remain contextdependent and evolve during a person's life-with respect to traits, at least during the formative years (Ahuvia and Wong 2002; Kasser et al. 1995; Kasser 2003; Roberts and Mroczek 2008). In the field of marketing, Black et al. (2017) argue that current materialism is partly the product of a neoliberal discourse that pervades consumer society and that governments should debate in order to trigger new forms of consumption. In political science, Inglehart's (1977) seminal theory of materialism proposes that materialism is expressed in different ways in people depending on the levels of economic and physical safety around them. Inglehart (1977) shows that rising levels of economic and physical safetyfor instance, after World War II in the West-contribute to intergenerational shifts toward what he calls postmaterial$i s m$, which is the prevalence of non-material goals, such as self-expression, belonging, and freedom of speech. In other words, consumers remain highly materialistic as long as they feel insecure about their finances and are unable to ensure their own and their families' safety. Similarly, consumers who experienced deprivation and insecurity during their formative years are likely to display more materialistic orientations, while financial and physical safety during their formative years could predict postmaterialism (Ahuvia and Wong 2002; Inglehart 1977). This well-supported theory is critical as it sheds light on the social influence that micro and macro environments have on consumers' materialistic orientation and on the idea that the meaning of materialism is likely to be modified as societies improve their economic performances. However, as with any other theory, it also raises some questions. For instance, Inglehart's (1977) theory tends to assume that less developed economies and poor consumers may not develop higher environmental consciousness as they are not socialized in a postmaterial environment. This assumption has been countered by theories and evidence showing that environmentalism exists in very diverse ways and countries, whatever the culture and the economic conditions (Dunlap and Mertig 1997; Guha and Martinez-Alier 1997; Morren and Grinstein 2016). An additional argument is that other sources of physical insecurity may appear in the life of consumers who are living comfortably. For instance, death anxiety triggers materialistic tendencies in some consumers (Urien and Kilbourne 2008). In a related vein, the current rise of eco-anxiety asks the question of its consequences for materialism: Would consumers who are anxious about climate change engage in higher or 
lower materialism? Finally, the use of the "post-" prefix may be one of the causes of these questions, as it indicates that postmaterialism would appear after materialism and would be something other than materialism. In this paper, we argue that expressions of materialism can evolve without having to change its name since the core idea-relying on materiality to situate oneself in the world-is unchanged. This is in line with Elgin's (1981) and Rudmin and Kilbourne's (1996) conception of materialism as a progression through different states. According to these authors, our relations to materials and possessions evolve depending on personal situations. While having relations of affluence to things is not possible for people living in poverty, Rudmin and Kilbourne (1996) emphasize how a voluntary refusal of material affluence is impossible unless one has experienced what material affluence brings to life. In their words, denying materialism is a "luxury" that only those who have experienced affluence can afford (Rudmin and Kilbourne 1996, p. 182). In the end, the progression of materialism they propose involves moving from involuntary simplicity or poverty (i.e., $-\mathrm{V}+\mathrm{S}$ ) to involuntary complexity or affluence (i.e., $-\mathrm{V}-\mathrm{S}$ ) to voluntary simplicity (i.e., $+\mathrm{V}+\mathrm{S}$ ).

Finally, well-accepted definitions of materialism (i.e., Belk 1984; Richins and Dawson 1992; Richins and Rudmin 1994) do not explicitly stipulate that materialism encourages people to accumulate more. Instead, and in line with these definitions, materialism invites people to put objects at the center of their lives and to use these objects in a symbolic way. In other words, there is an aspect of materialism that would be based not on an accumulation but on an appreciation of possessions, which we have largely ignored so far. For this reason, we use the terms accumulative materialism and appreciative materialism in this paper to propose another, more sustainable expression of materialism (i.e., appreciative) compared with the actual expression of materialism (i.e., accumulative).

\section{Polish Voluntary Simplicity and Materialism}

\section{Voluntary Simplicity}

VS, a term coined by Gregg (1936), is a voluntary "lifestyle of minimal, ethical, and ecological consumption" (Gopaldas 2008, p. 730). A simple and well-accepted definition of VS is offered by Etzioni (1998, p. 620), who understands VS as "the choice out of free will [...] to limit expenditures on consumer goods and services, and to cultivate non-materialistic sources of satisfaction and meaning." Related to asceticism and then to Ancient Chinese and European philosophies and religions (Gregg 1936; Rudmin and Kilbourne 1996; Zavestoski 2002), VS conveys the idea that we have to regain control of our lives and make them more meaningful by sidestepping the sprawl of mass consumption (Elgin 1981; Zavestoski 2002). VS is associated with environmental values, reduced consumption or material simplicity, distance from money, freedom, self-sufficiency, ethical principles, and spiritual and personal growth (Cherrier 2009; Cherrier and Murray 2007; Elgin and Mitchell 1977; Etzioni 1998; Gregg 1936; Huneke 2005; Leonard-Barton 1981; Moisander and Pesonen 2002; Shama 1981; Shaw and Newholm 2002).

It is commonly accepted that VS goes against materialism (Craig-Lees and Hill 2002; Etzioni 1998; Nepomuceno and Laroche 2015, 2017). One of the reasons is that one has to reject the having mode of existence in order to better serve the being mode (Cherrier and Murray 2007; Fromm 2013). Therefore, it becomes essential to reduce material consumption and remove superfluous or useless things (Ballantine and Creery 2010; Cherrier 2009; Cherrier and Murray 2007; Gopaldas 2008; Jackson 2005; Leonard-Barton 1981; Zavestoski 2002). In the same vein, VS is almost automatically considered as or partly explained by anti-consumption movements or/and counterculture (Alexander 2011; Maniates 2002; Witkowski 2010). Such an understanding comes from a long-lasting anti-materialistic ideology inherited from the counterculture of the 1960s and 1970s, which promoted the idea of freedom from the directive capitalist system and its materialistic values (Etzioni 1998; Zavestoski 2002). As a result, simplifiers are often seen in marketing as a segment of anti-consumers who resist the free-market ideology of accumulation and, more generally, materialism (Bekin et al. 2005; Iyer and Muncy 2009). Recently, VS has been described as a market mythology consisting of discourses well adapted to mass consumption (Gopaldas 2008) and as a practice of living in the consumerist market system (Shaw and Moraes 2009; Shaw and Newholm 2002). Moreover, the decision to resist consumption is sometimes made by materialists themselves (Nepomuceno and Laroche 2015). These recent findings support our observation that VS, at least in Poland, might not be as ideologically positioned against consumption or materialism as we generally expect but, rather, the expression of an appreciative form of materialism that conforms to the current economic system.

\section{Polish Simplifiers}

In Poland, and then in this paper, VS is used interchangeably with minimalism (Zalewska and Cobel-Tokarska 2016). Polish simplifiers are often in their mid-thirties or older and are, therefore, the youngest generation to have known and to remember the era of the Polish People's Republic (Kisielewska 2013; Klich and Siewiorek 2013). They grew up in a country that was facing a sputtering communist economic system and had stores that offered little to buy and where people had to queue for several hours because 
of central regulation. For most Polish people at the time, as was the case for East Germans (Veenis 1999), looking for goods took up a significant part of everyday life. Facing the typical scarcity of a shortage economy (Kornai 1992), they developed DIY types of strategies and were raised by hoarders collecting knick-knacks (Zalewska and CobelTokarska 2016). Also, as Verdery (1996, pp. 25-26) notes, this economy.

paradoxically abetted the emphasis on consumption. First, organized shortage made procuring something - anything - a major triumph. Second, even as the regimes prevented people from consuming by not making goods available $[\ldots]$ Socialism $[\ldots]$ aroused desire without focalizing it, and kept it alive by deprivation.

In the 1990s, when the country's communist economic system was replaced with a capitalist one, Western cultures of consumption reached Poland, and consumers started to crave branded goods. In a manner similar to what happened in Russia (Sutyrin and Vorobieva 2017), the end of market shortages and the entry into capitalism led many consumers to desire almost everything without any real knowledge of the promotional instruments developed by Western brands. As noted by Sexty (1998), Polish consumers moved from a situation in which everything was forbidden unless it was expressly allowed to an environment in which everything was allowed unless it was expressly forbidden. Free-market logic was supported by, on the one hand, consumers who were willing to change their consumption activities and decision-making processes and, on the other hand, brands that competed with each other through advertisements and the promotion of a Western standard of living (Johnson and Loveman 1995; Lofman 1993; Zalewska and Cobel-Tokarska 2016). Similarly to what Ger et al. (1993) observed in Romania, Polish consumers had a relatively simplistic and unrealistic view of the West, and especially the US, which was full of desired symbols such as freedom, quality, abundance, modernity, and status.

Another critical aspect of Polish culture to take into account is the influence of the Catholic Church in the country. Poles, both believers and non-believers, consider the Catholic Church in Poland to be "a bastion of freedom and a source of protection from and opposition to the communist authorities" (Eberts 1998, p. 817). While the influence of the Church has been waning for several years (Czapiński and Panek 2015), and despite ultranationalists' takeover of Catholic values (Santora and Berendt 2019), Catholicism still holds considerable sway over education and the law and, therefore, plays a significant role in Poles' social life (Pędziwiatr 2015). As Catholicism has a long tradition of simplicity rooted in Stoicism (Rudmin and Kilbourne 1996), as well as a deep-rooted tension between material opulence and simplicity (Bandak 2017), it may have played a role in shaping Poles' relations to materiality. Similarly, research has shown theoretically and empirically that religiosity and, more specifically, intrinsic religiosity are motivating factors of voluntary simplicity, in part because they discourage materialism in favor of spirituality (Chowdhury 2018; Huneke 2005).

\section{Polish Voluntary Simplicity: An Alternate Expression of Materialism?}

VS is usually understood as a resistance movement against materialism, a movement rejecting current consumptionoriented lifestyles to focus on well-being through ethical consumption (Cherrier 2009; Etzioni 1998). However, the time spent with participants produced a few more insights into some of the generally accepted findings of VS in the Polish context. While well-known motivations to embrace VS are still present (i.e., the need for material simplicity, self-determination, or personal growth), participants do not pay much attention to the ecological concerns or ethical principles that have been identified in other studies as simplifiers' motivating factors (e.g., Alexander and Ussher 2012; Leonard-Barton 1981; Shaw and Newholm 2002). In a similar vein, we have not identified clear anti-consumption attitudes in the sense of Zavestoski (2002, p. 121), that is, "a resistance to, distaste of, or even resentment or rejection of, consumption more generally." This is consistent with Kala et al. (2017) study of VS in the Czech Republic, which suggests that the country's socialist past might have developed a primarily self-oriented and less ideological version of VS.

This Polish (and potentially Eastern European) difference in VS leaves room for another expression of materialism that would be, in part, a consequence of its evolving form. As noted above, Rudmin and Kilbourne (1996, p. 183) consider VS to be deliberately denied materialism, being the product of "a progression of materialism" moving from involuntary simplicity or poverty to involuntary complexity to VS (i.e., $-\mathrm{V}+\mathrm{S} \rightarrow-\mathrm{V}-\mathrm{S} \rightarrow+\mathrm{V}+\mathrm{S}$ ). Within the space of just 50 years, Poles have experienced both involuntary simplicity $(-\mathrm{V}+\mathrm{S})$ through a communist economic system and involuntary complexity $(-\mathrm{V}-\mathrm{S})$ through the free market. As Ger et al. (1993) underline, consumers display greater levels of materialism in such post-communist conditions. However, with the free market in place for almost 30 years, it is now possible that levels of materialism have changed, as indicated by more recent research on Polish materialism (vs. American materialism) (Tobacyk et al. 2011). Finally, Kala et al. (2017) suggest that former communist or socialist economies create good conditions for less materialistic lifestyles such as VS to develop. For instance, activities like self-provisioning, bartering, and the DIY culture had already developed in communist and socialist economies. 
The consequences of capitalism and its free-market logic are not the only reason to develop forms of appreciative materialism. Because of market shortages during the time of the People's Republic, Polish consumers rarely threw things away because everything could have a second life. This is also visible in the former East Germany (at the time officially known as the German Democratic Republic), where some consumers who lived through the communist era reject today's throwaway society fed by the capitalist ideology and continue to store items in their basement in case of another possible shortage in the future (Albinsson et al. 2010). In this context, possessions are accumulated both to celebrate the new moments of abundance and feelings of freedom produced by the free market and to unconsciously reproduce ordinary safety measures and perpetuate the idea that another shortage is still possible. As we show below, it may be because Polish consumers had so many difficulties getting hold of what they wanted that they ended up developing highly respectful relations to objects over the years. This respect might also be the reason why some of these consumers are voluntarily returning to a more ascetic lifestyle after 20 years of engagement in mass consumption.

\section{An Ethnography of Appreciative Materialism}

We conducted a two-year ethnography with Polish simplifiers. Our objective eventually turned into gaining a better understanding of Polish simplifiers' relations to materiality and how it differs a priori from what we usually call materialism in our field (here, accumulative materialism). As indicated above, Poles have experienced both involuntary simplicity $(-\mathrm{V}+\mathrm{S})$ through a communist economic system and involuntary complexity $(-\mathrm{V}-\mathrm{S})$ through the free market over a period of just 50 years. Today, some of them are experiencing VS, and they make up most of the simplifiers we studied in this project.

\section{Data Collection and Analysis}

Our ethnographic study was carried out in three stages. The first stage took place over a period of nine months (March-November 2015). Interviews and observations were done across Poland by the first author; the vast majority of the participants live in big cities like Warsaw, Wroclaw, and Lodz. Observations were made in different contexts, from participation in fairs and farmers' markets to visits to local farms with participants, and continued throughout the different stages of the research. A total of 22 interviews were conducted in cafés and participants' homes. The second stage took place between November 2015 and April 2016. During this stage, participants were asked to take photographs on which they would later comment (Zaltman 1997).
Unfortunately, this exercise did not provide much more information than what we had already obtained through interviews and observation. The third and final stage, during which 15 additional in-depth interviews were carried out to verify previously collected research material and identified themes, was conducted between October 2016 and March 2017. The discrepancy $(n=7)$ between the number of additional interviews in the third stage and the number of interviews in the first stage results from a loss of contact with some participants (because of relocation or a lack of involvement) and from conducting many informal interviews during participant observation, which continued throughout the research and eventually replaced the more formal interviews of the third stage.

Following a naturalistic inquiry method, data collection and analysis were done simultaneously and followed an iterative process until saturation (Belk et al. 1988; Glaser and Strauss 1967). All the authors conducted the analysis and followed the logic of grounded theory by starting with open coding to focus on a few emerging themes-this is when relations to materiality strongly emerged (Spiggle 1994). Part of the coding process was done with ATLAS.ti by the first author. All interviews, photographs, and field notes were transcribed and separately added to this program's database. Preliminary codes were then developed through a process of tagging particular data segments, as well as constant comparison. After coding, the list of categories was established and compared with the results of the non-computerized analysis. As interviews were conducted in Polish, they were translated into English following the back-translation approach (Brislin 1970). Specifically, interviews were translated first from Polish to English with the help of both neural machine translation and human intervention on the basis of summaries of each interview originally written in English. Finally, interview excerpts were randomly selected and translated into Polish and compared with the originals in the source language. In total, the data that were generated produced 779 pages of transcripts from the 37 interviews: approximately $60.5 \mathrm{~h}$ of interviews, 200 photographs taken by 20 participants, and 40 pages of field notes.

The search for Polish simplifiers began by contacting the editors of thematic magazines, bloggers, and members of alternative organizations/associations or organizers of specific events who could recommend potential participants. The search continued during participation in events and through snowballing. The Internet proved to be a particularly helpful tool to find participants, with many of our participants being active on blogs about VS. A first criterion in the selection of the participants was self-identification, which means defining oneself as someone who follows the simplicity philosophy. By referring to these individuals following or being engaged in the simplicity movement, we mean they are committed to a way of life that they sought out for reasons 
other than poverty and involves limiting acquisitions and separating themselves from superfluous or unused goods. An additional criterion was the length of practicing simplicity: at least one year, although half of the interviewees declared they have had this lifestyle for more than five years. Drawing on the work of Etzioni (1998) and Shaw and Newholm (2002), we identified the participants as (1) strong, moderate, or low simplifiers based on their efforts to engage in VS and (2) hedonistic or ethical simplifiers according to their reasons for becoming simplifiers (from self-centered and based mostly on their own well-being to being tied to their concerns for the environment and social justice). As shown in Table 1, qualitative interviews were conducted with 17 women and five men aged 26-45 years. The interviewees were mostly women (75\%) between the ages of 26 and 45 . Almost all the participants were economically active; only two interviewees exclusively took care of home and their children. Finally, we ensured that the Polish simplifiers we interacted with, observed, and interviewed were not involuntarily embracing simplicity for financial reasons.

\section{Findings I. Quantity, Quality, and Symbolism of Possessions}

Many participants, like Zuzanna, share the view that "minimalism is opposed to materialism." However, to many of them, the quantity, quality, and symbolism of possessions still signal whether they are succeeding in their lifestyle or not. On the one hand, many respondents criticize ridiculous quantitative limits, bizarre criteria for usability, and the uselessness that can be found in downshifting manuals for beginners (e.g., Babauta's books). According to the participants, estimating the right number of possessions should be left to the individual and not be imposed on them by others. On the other hand, there is a constant focus on limiting the number of possessions since it is the most visible way for participants to define themselves as simplifiers. The aim of having less and less is discernible in Agnieszka's narration:

I would like to have fewer things in my life. I mean... I would like to reduce my possessions even more and have less than I currently do. I wish I could pack my items into two or three suitcases, you know. I don't know whether I'll be able to make it or not, but this is an ongoing process. And I am focusing on it right now. Step by step. You have to be patient [...] And you know the irony of this is that by constantly limiting [possessions], as I am doing now, you eventually become fascinated by things... because you stay focused on reducing more or throwing away. Always. So you're permanently thinking about the reasons for this object to be here, making deals like 'OK, I can probably keep this one, but only if I throw this one away'... So in the end, we count everything, and this can be very tiring. Really. More than having thousands of things. And the worst part is that I'm fully aware of this and that this is a kind of radicalism.

Agnieszka is one of many participants who moved from consumption extremism to non-consumption extremism. This focus on limiting possessions and counting the ones that remain becomes almost obsessive and, ironically, can be as time- and energy-consuming as a non-simple lifestyle. Despite the time and energy spent on such tasks, lowering the quantity remains necessary for happy living. While materialists, as described by Richins and Dawson (1992) and in later works, associate happiness and success with large amounts of possessions, our participants associate happiness and success with small amounts of possessions. This indicates that participants do not reject materialism per se but rather the currently promoted form of materialism, that is, one that is consumerist in nature (accumulative materialism). Interestingly, widely accepted definitions of materialism in our field (e.g., Belk 1984; Richins and Dawson 1992; Richins and Rudmin 1994) never put forward the accumulative tendency of materialism, but researchers have quite naturally considered materialism as accumulative. Materialism does not explicitly encourage people to accumulate more but invites them to center objects in their lives and use these objects in a symbolic way. As Agnieszka declares, "no object is wrong in itself if we know how to use it, if we know that it is convenient, useful, or simply gives us a great deal of pleasure."

When they reduce the number of possessions they have, the participants pay more attention to the quality of their future possessions, as well as their symbolism. Concerns about quality manifest themselves particularly strongly during the time allocated to purchasing. Spending the right amount of time to decide on the purchase seems to alleviate the sense of guilt that comes from accumulating things. It is a guarantee that the decision about buying a particular item or service was well-founded and made to satisfy personal needs. Participants complain that they are tired of the lowquality, temporary products available at chain stores. Also, while participants seem to be proud of not losing time in front of their wardrobe anymore thanks to simplicity, they nevertheless note that each purchase is preceded by a major time-consuming search to compare products, stores, and website offers with each other and to acquaint themselves with recommendations and user ratings. For instance, Adam spent months before buying his laptop as he had to examine the different features, the reviews, and the quality of the different brands and models - in order to keep his new laptop as long as possible. He says:

Just two months ago, I bought a MacBook, but I'd already started talking to Kamila [his wife] about the 
Table 1 Participant Characteristics and Summaries

\begin{tabular}{lllll}
\hline Pseudonym Age Gender Location & Occupation & Marital status & $\begin{array}{l}\text { Number; total } \\
\text { length of } \\
\text { interview(s) }\end{array}$ & $\begin{array}{l}\text { Number Profile of simplifier } \\
\text { of photos }\end{array}$ \\
\hline
\end{tabular}

Adam $\quad 37 \quad \mathrm{M} \quad$ Wroclaw $\quad$ Event manager $\quad$ Married $\quad 2 ; 3 \mathrm{~h} 15 \mathrm{~min} \quad 10 \quad$ Moderate/ hedonistic

VS enables Adam to prioritize his values and goals. He definitely links simplicity to a slower life and a healthier lifestyle. He puts his family first; everything else is secondary. He emphasizes that there is a discrepancy between VS as shown in the media and how it is in real life
Agata
45 F Countryside Unemployed
Married
$1 ; 1 \mathrm{~h} 4 \mathrm{~min}$
0
Agata, a 45-year-old unemployed mother of four children, discusses her commitment to VS in terms of taking care of her family. She links her simplicity with producing healthy, homemade food, using natural cosmetics, and spending more time in nature
Agnieszka

\section{F Warsaw Lawyer}
Unmarried 2; $3 \mathrm{~h} 9 \mathrm{~min}$
10
Agnieszka has her own company and focuses on issues such as awareness, independence, and freedom. In her view, VS means freedom from an abundance of material things, which gives her spare time

Moderate/ hedonistic

Moderate/ hedonistic
Aneta
Unmarried
$2 ; 2 \mathrm{~h} 45 \mathrm{~min}$
10
Aneta describes her VS in philosophical and spiritual terms. In her view, by knowing the value of true meditation and of true spiritual aspects in our daily lives, we may be better connected to other people, the environment, the planet, and ourselves

Moderate/ hedonistic
Anna
Countryside Organizer of cultural activities Married
2; 5 h 23 min
10
For Anna, VS encompasses three categories: awareness, balance, and celebration (in particular, family time). She tries to be a conscious consumer by choosing local food and screening products and brands to ensure she makes choices in keeping with her ethical concerns
$\begin{array}{lll}\text { Bartosz } & 36 \quad \mathrm{M} \quad \text { Countryside Agri-tourism business owner } \quad \text { Married } & 1 ; 1 \mathrm{~h} 59 \mathrm{~min} \\ & \text { For Bartosz, VS makes it possible to establish deeper ties with his family, in particular his children and his } \\ & \text { wife. His simplicity is strongly motivated by faith, which is reflected in various religious practices }\end{array}$

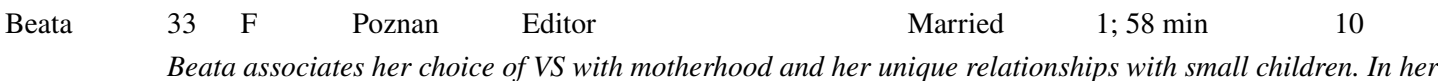 opinion, taking care of children is the best lesson for mindfulness, love, and emotions. She does experi- ence conflict between her minimalistic assumptions and her real family needs

Moderate/ hedonistic
Dorota
Warsaw Manager in NGO
Unmarried 1; $1 \mathrm{~h} 45 \mathrm{~min}$
10
Dorota's VS is related mostly to her vegetarianism, as well as environmental and health concerns. She supports the "eat less, eat better" rule, which means using fresh ingredients, having one's own herbs, and trying to have only well-balanced meal

Moderate/ hedonistic
Emilia
$45 \mathrm{~F}$
Countryside Unemployed
Married
2; 3 h 50 min
10
Low/ hedonistic

Emilia is an unemployed mother of three children. She associates simple life with "slow life" and sees it as an opportunity for personal enrichment-including better self-knowledge and better health

Jacek

41 M Countryside Judge

Married

2; 2 h 55 min

10

Jacek lives in the countryside near Warsaw. His commitment to VS is strongly motivated by religious and family reasons. For Jacek, "real" Christians do not need a lot of possessions because true faith plays a central role in their life. He supports local production and local community initiatives like free-food exchanges

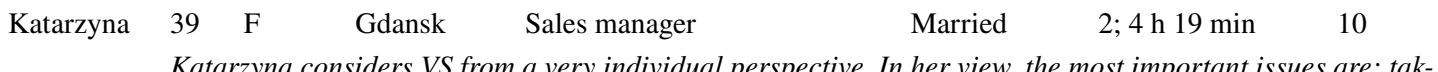
ing care of oneself, discovering one's self, exploring one's own needs, and having the right amount of free time to spend on hobbies and passions
Magdalena
37 F Lublin Own business
Unmarried
2; 3 h $56 \mathrm{~min}$
10
Magdalena runs her own foundation. VS allows her, above all, to get to know herself better. She holds strong views regarding her choice of a vegetarian diet and alternative medicine practices
Małgorzata
26 F Warsaw Jewelry designer
Unmarried
$2 ; 2$ h 56 min
10
Matgorzata is interested in the philosophical roots of and relations to VS. Her current concerns relate to human relationships with nature. Her consumption choices, from clothes and groceries to interior design, clearly underscore a VS taste that is shared among simplifiers

Moderate/ hedonistic
Martyna
Warsaw Advertising specialist
Unmarried $\quad 1 ; 2 \mathrm{~h} 4 \mathrm{~min}$
10
For Martyna, VS is closely related to slow fashion and slow travel practices, which are seen as a way of

Low/ hedonistic

Low/ hedonistic reaching self-fulfilment. By adopting VS, she discovered many ways to live and consume more consciously 
Table 1 (continued)

\begin{tabular}{|c|c|c|c|c|c|c|c|c|}
\hline Pseudonym & Age & Gender & Location & Occupation & Marital status & $\begin{array}{l}\text { Number; total } \\
\text { length of } \\
\text { interview(s) }\end{array}$ & $\begin{array}{l}\text { Number } \\
\text { of photos }\end{array}$ & Profile of simplifier \\
\hline \multirow[t]{2}{*}{ Monika } & 27 & $\mathrm{~F}$ & Countryside & Yoga instructor & Married & $2 ; 2$ h 5 min & 10 & Moderate/ hedonistic \\
\hline & \multicolumn{7}{|c|}{$\begin{array}{l}\text { Monika doesn't make a clear distinction between VS and slow life. For her, both shape consumer behavior } \\
\text { by making people pay closer attention to having smaller amounts but better quality of products, as well as } \\
\text { a better quality of life. The "no waste" rule also plays a key role in her daily choices }\end{array}$} & \\
\hline \multirow[t]{2}{*}{ Natalia } & 31 & $\mathrm{~F}$ & Countryside & Agri-tourism business owner & Married & $1 ; 1 \mathrm{~h} 59 \mathrm{~min}$ & 10 & Strong/ hedonistic \\
\hline & \multicolumn{7}{|c|}{$\begin{array}{l}\text { Natalia puts an emphasis on family and religious issues. Implementing VS led her to greater involvement in } \\
\text { daily activities and closer relationships with her husband, children, and other relatives }\end{array}$} & \\
\hline \multirow[t]{2}{*}{ Ola } & 35 & $\mathrm{~F}$ & Lodz & Mindfulness instructor & Married & $1 ; 57 \mathrm{~min}$ & 0 & Low/ hedonistic \\
\hline & \multicolumn{7}{|c|}{$\begin{array}{l}\text { Ola links VS to her vegetarianism and healthy lifestyle. Apart from regular yoga exercises, she practices } \\
\text { meditation every day and believes in alternative Chinese medicine. She seeks consistency between per- } \\
\text { sonal needs and family responsibilities }\end{array}$} & \\
\hline \multirow[t]{2}{*}{ Piotr } & 42 & M & Warsaw & IT specialist & Married & $2 ; 3 \mathrm{~h} 32 \mathrm{~min}$ & 10 & Moderate/ hedonistic \\
\hline & \multicolumn{7}{|c|}{$\begin{array}{l}\text { Piotr sees numerous similarities between VS and Catholicism. For instance, simplicity provides space to } \\
\text { build less materialistic relationships between people, particularly between relatives. However, he admits } \\
\text { he is sometimes distracted and does not engage in what he would consider more ideal simplifier behaviors }\end{array}$} & \\
\hline \multirow[t]{2}{*}{ Renata } & 36 & $\mathrm{~F}$ & Wroclaw & Event manager & Married & $2 ; 3 \mathrm{~h} 15 \mathrm{~min}$ & 10 & Moderate/ hedonistic \\
\hline & \multicolumn{7}{|c|}{$\begin{array}{l}\text { Renata runs an event company with her husband. She associates VS with better relationships with rela- } \\
\text { tives, as well as more aware consumer choices, especially regarding food. She puts special emphasis on } \\
\text { 'second-hand practices' that give things 'a second life' (e.g., furniture) }\end{array}$} & \\
\hline \multirow[t]{2}{*}{ Sylwia } & 30 & $\mathrm{~F}$ & Katowice & Translator & Married & $2 ; 2 \mathrm{~h} 21 \mathrm{~min}$ & 10 & Moderate/ hedonistic \\
\hline & \multicolumn{7}{|c|}{$\begin{array}{l}\text { Sylwia sees VS as a way to limit the number of possessions and develop her sense of self. As she has a } \\
\text { young daughter, she is also very aware of the challenges and difficulties of keeping her life simple }\end{array}$} & \\
\hline \multirow[t]{2}{*}{ Tomasz } & 32 & M & Warsaw & IT specialist & Unmarried & $2 ; 2 \mathrm{~h} 42 \mathrm{~min}$ & 10 & Moderate/ ethical \\
\hline & \multicolumn{7}{|c|}{$\begin{array}{l}\text { Tomasz's views and beliefs are undoubtedly shaped by various Eastern philosophies. He has a very holistic } \\
\text { approach to ethical production and consumption and is interested in the connections between people and } \\
\text { nature or people and animals }\end{array}$} & \\
\hline \multirow[t]{2}{*}{ Zuzanna } & & $\mathrm{F}$ & Cracow & Translator & Married & $2 ; 3 \mathrm{~h} 25 \mathrm{~min}$ & 10 & Moderate/ hedonistic \\
\hline & \multicolumn{7}{|c|}{$\begin{array}{l}\text { Zuzanna strongly associates VS with her experience of living in communist Poland. She places special } \\
\text { emphasis on individual 'agency,' and independence matters a lot to her }\end{array}$} & \\
\hline
\end{tabular}

necessity of purchasing a Mac last year. And finally, when I found that I really needed this type of computer, I bought it. It was not a matter of impulse because before buying a Mac I had been considering all the options: where I could buy it, what the best price was, and so on. In the end, I knew almost everything about laptops, what makes them good or bad, the potential technical problems you may have... I think I could have won the best salesman contest! But it's important. We buy these things to make them last. So it's better to have the best.

Similarly, one of the youngest participants, Martyna, recounts the story of her obsession with a very particular navy coat that she had been considering for months and was even ready to import it from the United States if necessary:

I have a perfect picture of this coat in my head, and I won't make any concession [...] I know I want a navy coat, a calf-length navy coat to be more precise, because I've seen one like this in Berlin. I fell in love with this coat when I saw it, and now I have a clear picture of it here [she points her head]. So I've decided to buy exactly the same, but it is very hard to find... almost impossible, in fact [...] But the problem is that if I don't find what I want, I won't buy anything. And I desperately need a coat now because mine is just irreparable... and it's getting cold. But I want this coat, not another one. I want something that I like very much and that is good quality. So I haven't stopped looking for it, with no concession possible. I will look for it, for example on Allegro, eBay... I will import it from the United States if necessary.

Adam and Martyna's focus on quality and product characteristics fits their fierce rejection of compulsive buying, which they regard as a symbol of accumulative materialism. In a utilitarian approach to shopping (Babin et al. 1994), Adam and Martyna's search for quality takes the form of a well-engineered search protocol in service of performance. In this vein, utilitarian shopping value is 
like a precondition to perform simplicity-the idea being that having less implies having better-quality items, which means having to rationalize the purchase. However, the well-engineered search protocol that was implemented can also provide a more hedonistic and, thus, pleasurable approach to shopping. For instance, Martyna's search for the perfect navy coat is perceived as an adventure, a hunt "with no concession possible." The idea of getting exactly the coat she has in mind is exciting to her.

In parallel to their focus on quality, participants pay attention to the symbolic power of their possessions, which is partly motivated by identity projects. For instance, Adam's MacBook is not only the result, as he says, of a long period of reflection. Many other brands that are less expensive would have provided the same level of functionality. But a MacBook symbolizes purity of shapes, sobriety, minimalism, and creativity. Simplifiers have developed a sense of aesthetics that prevents them from making purchase decisions based solely on well-designed, comfortable, and utilitarian features. This sense of aesthetics is partly influenced by the cultural codes and taste shared among simplifiers and is materialized by particular objects. For instance, many participants spend large amounts of money on books while they could go-as we could expect from simplifiers- to the library and stop buying non-essential objects. Interestingly, for some participants, this interest in books came later, when they engaged in VS. It seems that books, like home interiors, might be part of group mimesis and a particular habitus (Bourdieu 1979). Just like these objects delimit the VS movement, they strengthen simplifiers' feelings of belonging to it. When talking about her new minimalist (maritime) home style, which prevents her from keeping her previous veils, Anna demonstrates this minimalist taste:

When we moved, I looked a lot at things that we had in the attic to avoid buying them again. For example, I had veils in a former house with a completely different home interior. These veils are really nice, and I've spent a lot of money on them and the interior that I had... [...] So it would be a shame not to reuse them, but at the same time it doesn't suit my new minimalist interior at all. So I've finally changed them.

While identity-driven consumption is visible in participants, it is, above all, identity-driven non-consumption that characterizes participants' relationship to the marketplace. Refusal plays an important role in participants' identity shaping, and gives even more credence to the existence of a VS taste that includes as much as it deliberately excludes a large part of consumers.
Findings II. Alternate Statuses, Alternate Encounters

We observe a general trend toward a decommoditization of participants' possessions, which reflects a change in the status given to these possessions and the caring type of relationship developed with them. This is illustrated, for example, by Agnieszka, who shows respect to the "people who create our things" and says that "if people treat their things with respect, they feel a connection to these things." Objects are not just objects: They have their own story and should, therefore, be respected. Objects have moved from having a status of a simple commodity on the side and at the service of consumer centrality to having the status of an interconnected object that comes from and expresses a decentered consumer's environment. This new status for objects reflects a different relationship to them that is based on respect and what Tokarczuk (2019) calls tenderness: giving things existence, giving them time, space, and care, and, more generally, seeing things as interconnected and working in cooperation with people.

This change of status for objects is partly related to the collective history of Poles, which led our participants first to a lack of respect toward objects in the early years of the free market—as exemplified by accumulation — and second to higher levels of respect through non-accumulation. For instance, Zuzanna linked her previous excessive accumulation of possessions to a childhood spent in poverty, the harsh reality of her and other Poles being enslaved because of a lack of material objects and being forced to spend many hours in long queues to get basic products. She says:

This plethora of things was definitely associated with my poor childhood, which was obviously materially unattractive. You know, I remember myself standing in long queues to buy goods [...] So first I would say those material restrictions at home, in our family. Second, the collapse of the communist system in 1989, when we started experiencing materialistic improvement, and life began to look more, let's say 'normal'... but still, there were some shortages.

For Zuzanna, who had grown up with the communist economic system, excessive consumption was an unconscious form of compensation for previous shortages. Moreover, the overabundance of goods partly stems from strategies developed during times of economic scarcity, such as hoarding dispensable objects and never throwing them away. Zuzanna said that in the past she was driven by a typical communist approach that considers each object, even souvenirs, as useful, so every single thing should be kept. As a result, her cupboards, wardrobes, and basement became storage areas for long-forgotten objects. Today, this communist past associated with a feeling of security regarding the future availability of products on the 
market has led Zuzanna to show greater respect toward objects. Similarly, Małgorzata, who is too young to have lived through the People's Republic but still grew up with remnants of it, shows respect for objects through what she calls awareness:

the more I've increased my awareness of what material is and what it involves, the more I've narrowed down the range of my possessions. I think it started when I was in this jewelry school and what I did there with raw materials. It is being aware of the beauty of things, giving attention to our surroundings. This is also something I've learnt when taking photographs.

In Poland today, the widespread availability of the basic products that provide participants with a comfortable life has led Zuzanna, Małgorzata, and others not to care about an object because of its scarcity on the market but because it has been, in a way, rationalized. By rationalized, we mean the magical thinking that characterizes consumer society and creates distance between the product and the consumer has shrunk for the benefit of the reality principle. Objects are wrapped up in reality in the sense that participants are interested in what is usually hidden by marketers, such as how and by whom objects are made and how they are distributed. Material possessions no longer take consumers away from reality but help them to better apprehend reality.

Interestingly, when it comes to environmental consciousness, this return to reality is more evident for consumable, daily-use products than for durable ones. For instance, levels of environmental consciousness remain weak for durable goods despite a rationalization of the object. In the search protocol that participants have put in place before the purchase, the products' environmental impact is taken into account but does not seem to have more weight than other factors; the idea is that keeping only a few possessionsand for a much longer time than what mass consumption requires - is the real environmentally friendly behavior. The problem, for Magdalena,

is not that what I buy is not local. Of course, here I'm talking about things I don't buy regularly-not food and what we need every day or every week. For these products [i.e., regular purchases], I think it's very important to buy local. But for the rest... something that we will keep with us for long, I think the problem is not that it comes from far away. If I buy shoes [to last] for years, it's not a problem in general because I usually keep them for a long time. I buy less but [these are] more durable, good-quality things, so I don't feel bad if it comes from far away or if I drive far to get it.

Participants have the privilege of not caring too much about the environmental impact of their durable goods because their purchases are not frequent and, therefore, in their eyes, not very harmful compared with accumulative materialists' frequent and numerous purchases.

Environmental consciousness is more visible for dailyuse goods, such as food, because they represent regular and frequent purchases. Environmental consciousness is visible, for instance, through psychological, social, and geographical proximity with the producer and the conditions of production. As Anna notes:

I usually buy potatoes from a neighbor who grows them himself. It is not far from here. The eggs also come from the neighbor's property. I also buy apples, vegetables, and fruit that I can't grow on my own. We always buy strawberries in the neighborhood, where I know they haven't been processed. I've seen them grow from the beginning. That makes all the difference. We give our best to cultivate fruit and vegetables here in the backyard, but the result is that he [the neighbor/farmer] does that far better than us. More generally, we try to buy everything in the neighborhood. This is important to know what happens to what we eat, how it is made, etc.

Special attention is given to supporting native, local, and seasonal production. Also, many participants enjoy preparing their own products (especially preserves, like jams and salads) and planting their own aromatic herbs and vegetables in home gardens or pots on the balcony. However, the participants are motivated less by saving the planet than by respecting it and living in harmony with it. In this vein, participants return to the primary meaning of the word ecology, which is often associated with environmentalism today. Similarly, the term environment also seems to be more associated with its primary meaning (i.e., surroundings in which living and non-living entities operate) and does not necessarily have a green aspect to it. Deciding to reduce consumption is related to an increased awareness of what it means to consume on a daily basis when one is part of the same environment and that this environment is under pressure and not magically able to expand. In a consumer society that favors accumulative materialism, daily-use products are provided by grocery stores that display an uninterrupted and abundant flow of merchandise. For the participants, there is a need to rationalize these goods by reconnecting them with their environment and making them limited, fragile, and self-governing resources that people depend on. As Ola, Dorota, and some other participants believe, the fact many children today think that fruits and vegetables come from stores instead of nature and would be available at will and instantaneously is a dangerous disconnection from reality that should be rejected.

Whatever the product is, the return to reality is also perceptible through the idea that good things in life do not come easy and that consumption is like a reward. Just like fruits 
do not come from the grocery store but need time to grow and grow only if good conditions are met in participants' or farmers' gardens, more durable goods become possessions if the participants develop a narrative of struggle regarding the possibility of having them in their possession. This struggle can be, for instance, the large amount of time spent searching for the right product, making the product on one's own, or the difficulties that have to be faced to acquire the right product. Regarding Martyna's obsessive search for the perfect navy coat in the previous section, her endeavor stresses a motivation to develop meaningful stories and relationships with objects, regardless of the distance and associated $\mathrm{CO}_{2}$ emissions that this coat will produce. By struggling to obtain a product, Martyna is already creating memories and preparing a narrative for future possession, which she wants to be sacred (Belk et al. 1989). While she already has a backpack from Sweden that she meticulously cleans and a purse from Morocco that is "really [hers]," Martyna sees in this navy coat located in the US the possibility to have a nice story that will singularize and decommoditize (Kopytoff 1986) her new, difficult-to-get, and supposed-to-last possession.

This alternate status given to objects has yielded alternate encounters. Participants have developed privileged relationships with objects on the basis of proximity, attachment, and commitment. Proximity is not necessarily geographical proximity with products (e.g., buying local products) but also a reduced psychological distance brought about by a low quantity of objects and the knowledge gained from and about possessions. Simply put, participants acknowledge that the less they have, the more they care. And the more they care about their possessions, the more they know about them and feel a connection, according to Agnieszka. In a different vein, Monika relates how she buys very little cosmetics but knows her products very well and can use them on their own or in combination with each other to great effect without accumulating and wasting:

Simple life also manifests itself in my consumption of skincare products. My friends know that I have a limited number of cosmetics, but most people are surprised to see how little I have and don't understand how it is possible. Well, it is possible! Most of the time we buy plenty of products that are supposed to work on a particular part of our face, with specific aims, etc. But in the end, we don't even know what they really are or what they contain, so we use them as the brands say. And we buy them again and again. Thanks to minimalism, I became familiar with the contents of all these products, how they can be used in other circumstances, methods of application, and so on. And I can tell you that this is very instructive because, in the end, you realize that you can take care of yourself and your skin with only half of these products, even less. And since you buy less, you can buy better, more natural products, which is a true pleasure.

The more participants care about their possessions, the more they get attached to them. Possessions accompany simplifiers at every moment of their life and trigger many positive emotions and attachments. Limited possessions become carriers for memories and experiences. Even an a priori ordinary item like Małgorzata's white mug becomes cultic and the object of rituals. Similar to the story of Martyna's navy coat, Małgorzata owning only one mug, which she has carefully chosen from among thousands of other mugs, inevitably makes this one unique and beautiful, just as it gives Małgorzata's tea a particular flavor. When it comes to family souvenirs, Sylwia sees "greater sense in having fewer souvenirs, but souvenirs [...] that will be treated with such devotion that they will always remind us of something very important." Another reason why participants attach such importance to their possessions is that some of these items have not been bought but are ones that they, their friends, or their relatives created. In addition to the feelings of authenticity and uniqueness conveyed by the handmade creation, these objects connect participants to the ones they care for but also to themselves.

Finally, the more participants care about their few possessions, the more they commit to manipulating them effectively, repairing, or even upcycling them. According to Renata, one of our participants, her approach to consumption consists of (re)using existing resources:

I call it 'using existing resources.' There's no need to always buy new things while throwing others out. This is just insane. We don't realize how much we can do with what we already have. Of course, we don't even know what we have! We don't take care of it. And this is a shame because it actually takes less time and is cheaper to take care of what we have and to recycle. We need less time, less money and, of course, we produce less trash, when we decide to renovate our old furniture or to repair our clothes. I mean, all these actions-repairing, renovating, restoring-are often less time- and money-consuming. It will definitely take you less time to go to the nearest store, buy paint cans, and repaint a chair than spending hours on the Internet or in stores to find some super special chair that you like because the old one is already out of fashion.

According to Renata, her commitment helps her to better connect with and adjust to reality. Similarly, many participants have rediscovered enjoyment in simple manual activities (e.g., gardening, needlework, crochet, and ceramics) that make them realize how much objects depend on natural resources and require effort to be produced. Interestingly, the participants do not perceive this commitment 
to possessions — and matter, more generally_as effort or a concession that has to be made. As Renata mentioned above, it even saves her time that she and other participants did not have before. Commitment to matter has helped some of the participants put an end to their inner clash between material excess and feelings of emptiness, including Anna, who used to have a luxurious apartment with "a TV set, radio, DVD player, and other devices [...] a vast amount of clothes" and "bought, bought, bought a lot because [she] worked for it." At the same time, however, she felt empty and was desperately trying to fill a void that she could not clearly identify. When her son was born, she realized that all this abundance did not make any sense: "And it was so sad, because apart from material things and work, I had nothing, you know, not even time for my husband."

\section{Discussion}

\section{What Appreciative Materialism Is}

This ethnography sheds light on another expression of materialism-appreciative materialism - that we believe to be more sustainable and illustrative of new materialism and, more generally, of a zeitgeist return to matter. This research underlines the critical role of possessions in the lifestyle of Polish simplifiers, but it does so by emphasizing their absence or scarcity and without the simplifiers having any intention to accumulate more. As a result, we advise against considering materialism only (or mainly) as an accumulation of goods. Moreover, we suggest differentiating between accumulative materialism, which corresponds to an expression of materialism that promotes the accumulation of objects, and appreciative materialism, which favors the nonaccumulation of objects but still puts objects at the center of people's lives. Accumulative materialism has already been well documented. Because it is associated with an accumulation of goods, it has often been considered as the possibility for economic growth and wealth on the one hand and as a barrier to sustainable and ethical behavior on the other hand (Muncy and Eastman 1998). Also, it is generally accepted that accumulative materialism has negative impacts on consumers and society with regard to well-being, ethics, and environmental concerns (Kasser 2003; Kilbourne and Pickett 2008; Kotler 2011; Richins and Dawson 1992).

Appreciative materialism also obeys a materialism-oriented philosophy. Like accumulative materialists, appreciative materialists take part in the game of consumption and spend time choosing products because objects are important to their lives. Unlike accumulative materialists, however, they focus on the non-acquisition and non-use-rather than the accumulation-of objects and create meanings from such a refusal. Taste is, above all, a matter of distaste
(Bourdieu 1979). And as Wilk's (1997, pp. 183-184) study in Belize shows, "not having, not wearing, not eating, can be just as much a form of conformity or social distinction as having, wearing, or eating." Belk (1988) argues that one can extend one's self simply by knowing something, just like money has the power to enlarge the sense of self by providing potential possibilities regarding what we might have and do with this money. Objects have symbolic meaning that consumers internalize and/or use to express/construct themselves (Belk 1988; Douglas and Isherwood 1979; Levy 1959; McCracken 1986). Drawing on the work of these authors, we argue that appreciative materialism is fueled by the physical absence of objects since this absence triggers high symbolic (but invisible) consumption. Through their acts of refusal, appreciative materialists acknowledge the existence of a meaningful system of objects provided by the market. This importance of an absence is visible when consumers construct their identities around the idea of saying "no" to brands or products (Banister and Hogg 2004; Klein 1999; Kozinets and Handelman 2004). For instance, Muslim and Jewish consumers may voluntarily renounce eating pork in order to have a stronger sense of their Muslim or Jewish identities, while people with healthy lifestyles generally give up smoking. Similarly, not having guns in the US, where half the population wishes to protect the right to own a gun, may be symbolically as important as owning a gun (Parker et al. 2017). In marketing, the importance of an absence is also visible, for instance through brand avoidance, brand hate, and consumption anti-constellations (Gregoire et al. 2009; Hogg 1998; Kucuk 2016; Lee et al. 2009).

A critical aspect of appreciative materialism is the enactment of a caring ethics that extends to non-humans. The alternate status of objects allows participants to develop proximity, attachment, and commitment that originate from the very materialistic idea that matter is what makes our world and that we are part of this world, so one should maintain sustainable and respectful relationships with objects and, more generally, with matter. In line with Tronto (1993), who considers caring to be a manifestation of being in the world, we also interpret participants' appreciative materialism as a manifestation of being in the world - a possible answer to hyperreality, which has led many consumers to lose sight of reality, often in aid of the pleasure principle. Participants in our ethnography need to manipulate objects and learn about them, their history, and the consequences related to their use, just as they are willing to repair or upcycle them. We believe these findings complement Shaw et al. (2015) study on consumers' expression of care in the context of ethical consumption. Care plays an important role in ethical consumption, and developing an extended ethics of care that includes the way we treat things in and for themselves plays a decisive role in attaining a more sustainable and ethical form of consumption. Interestingly, digital possessions 
are not as respected and cared for by participants as physical possessions are. For instance, many of the participants consume and store massive-scale digital versions of movies, books, newspapers, and music, and accumulate pictures on their mobile phones, laptops, tablets, and/or e-readers. A possible explanation is the lack of proximity and attachment that one may have with digital possessions, which possibly comes from a different status given to them. In addition, this hypothesis would accentuate even more the importance of having both proximity and attachment in the development of caring.

These findings and interpretations should, of course, be nuanced as appreciative materialism was observed and studied in the Polish context, which has a particular political and economic history that is different from that of Western capitalist economies or Eastern cultures and their philosophical legacy. For example, the ontological reasons behind appreciative materialism can differ from one culture to another, depending on the status given to objects. For instance, new materialism and animism are monistic concepts that make humans and non-humans cohabit, which possibly leads to appreciative materialism. However, we argue that new materialism accepts things for what they are (i.e., a non-human object with its own life sometimes independent of human will and without human characteristics), while animism takes a more anthropocentric perspective by attributing human forms of thinking and behaving to matter (Descola 2005). Therefore, we encourage researchers and decision makers to familiarize themselves with the context in which consumers express appreciative forms of materialism. While we believe the low quantity of possessions will remain unchanged in appreciative materialism, we expect variance in caring practices toward possessions and matter from one (sub)culture to another.

\section{Updating What Materialism Is and How to Measure It}

Materialism is an evolving phenomenon, and using old scales might be problematic. One major issue we find with current materialism scales, at least the most-used ones (Belk 1985; Richins and Dawson 1992), is their focus on accumulative materialism. This is a problem because an appreciative materialist would wrongly be considered a low materialist according to these scales. For example, Belk's (1985) three traits (i.e., possessiveness, non-generosity, and envy) fit into accumulative materialism but do not entirely fit into appreciative materialism. In particular, the non-generosity trait that corresponds to "an unwillingness to give possessions to or share possessions with others" (Belk 1985, p. 268) does not reflect our participants' willingness to give, lend, or share the possessions they have acquired or even produced in the case of fruit and vegetables. Because appreciative materialism extends the caring ethics to things, appreciative materialists share and give their possessions. This is the case with Monika, for example:

My mother always taught me not to throw things away. If I bought something and it broke, I had to fix it. I remember when I moved with my parents and a large family was living nearby, we would give them clothes, books... I thought it was so cool because we didn't need them anymore, and they needed those things... There's always another way to get rid of things but in a positive way. That's why all these blogs annoy me where people often write, 'Open your wardrobe and throw out $90 \%$ of the stuff you have!' For me, it's just ridiculous because they didn't just magically happen. We paid for these things, and somebody made them.

Participants like Jacek, Anna, Magdalena, and Monika often exchange possessions (e.g., clothes for clothes, clothes or books for food...), share products from their garden, or simply give toys to their neighbors. This can take the form of true sharing (Belk 2010), as Anna mentions:

we enjoy it, we like it, and it is nice for my neighbors, too. It isn't like someone is forced to give me something and I have to give something else in return. It works naturally.

It can also take on a more utilitarian form through a more pragmatic form of sharing, such as collaborative ownership (Belk 2010), which goes against some of Belk's (1985) items on the possessiveness subscale, like "I would rather buy something I need than borrow it from someone else" (Belk 1985, p. 270). Similarly, Richins and Dawson's (1992) and Richins's (2004) items composing the three dimensions of centrality, success, and happiness were developed according to an accumulative understanding of materialism. Therefore, it is not possible to answer, for instance, that "I usually buy only the things I need," or "I try to keep my life simple, as far as possessions are concerned" without being wrongly categorized as a low materialist. While we believe a low accumulative materialist may have commonalities with an appreciative materialist in terms of accumulation, they are still two different profiles. One of the main differences is that low (accumulative) materialists do not put great emphasis on possessions and objects in general, which makes them closer to spirituality than appreciative materialism.

While these well-used scales have proved to be valid and reliable over time, their validity is called into question the moment one considers appreciative materialism not as low materialism but as an alternate expression of materialism. In this context, Belk (1985), as well as Richins and Dawson (1992) and Richins (2004), should not be replaced (i.e., they are still accurately measuring one expression of materialism that we define as accumulative in this paper) 
but updated to make them fit evolving expressions of materialism. Drawing on the present research, we contend that the enactment of an ethics of caring that extends to nonhumans is an important aspect of appreciative materialism and should be measured with new items. Building on Belk (2010, p. 728), who stresses that "sharing is caring" while he contrasts true sharing with (accumulative) materialism, we believe this aphorism might also be true regarding appreciative materialism and the caring ethics extended to non-humans it involves. In this regard, literature about caring in nursing studies and philosophy, in addition to what has been done in management (Shaw, McMaster, and Newholm 2015), should be explored to develop new items related to the caring relations developed between things and non-human matter in general (whether they are possessions or not) and consumers. For instance, caring items related to proximity (e.g., "I sometimes feel connected to objects/possessions," "I know where and how most of my possessions have been made," etc.), attachment (e.g., "My possessions occupy a special place in my life," etc.), commitment (e.g., "I always learn how to use a product correctly before using it to make the most of it"; "I always try to fix a broken object or give it another function before throwing it away," etc.), or respect (e.g., "I never buy something that I don't really like," "I have respect for my possessions and objects in general," "I like the idea that possessions I don't use anymore will have a second life with someone else," "It is not because objects are outdated that they should be replaced," etc.) could be developed and tested.

In line with this reconceptualization and measurement of materialism, researchers should also look into traditionally held consequences. For instance, what would be the findings of research into the relationship between well-being or happiness and the level of materialism if one added this less-visible and non-tangible expression of materialism that we call appreciative materialism (Burroughs and Rindfleisch 2002; Karabati and Cemalcilar 2010; Pandelaere 2016)? Moreover, unexpected positive relationships were shown between materialism and, for instance, anti-consumption, environmentalism, or sharing behaviors (Davidson et al. 2018; Nepomuceno and Laroche 2017; Strizhakova and Coulter 2013). While these relationships initially appeared to be surprising, considering low materialism and appreciative materialism as two different things may help to better understand why these relationships were found and are ultimately not that unexpected. More generally, refining the measurement of materialism by including caring-related items, for example, may not only enrich our understanding of materialism but also contribute to an alternate ethics for consumption that diverges from the anti-consumption and anti-materialism ideologies.

\section{Appreciative Materialism and Sustainability}

We mentioned in the introduction that one of the main dilemmas facing business ethics today is how to maintain profitable relationships with consumers while preserving the environment. We argue that, in the long run, appreciative materialists may have a more positive impact on the planet than consumers who resist consumption by sidestepping the market-provided we accept that the world is not ready to abandon capitalism. Just like ethical consumption, appreciative materialism can become this side movement that criticizes the consumerist market while remaining a part of it in order to change it. In a market that can barely be escaped (Kozinets 2002), appreciative materialism is one of the possible responses to Scott et al. (2014) call for new relations to materiality. While Scott et al. (2014, p. 288) argue that "asking consumers to be less materialistic does not work" and that reduced consumption can be part of the answer to sustainability, appreciative materialism shows how objects can be part of a sustainable solution.

Regarding the question of whether buying less allows brands to make a profit, we believe this is primarily a (political?) question of a paradigm shift. While it is true that, in our current economic model, not many brands would survive appreciative materialism, we believe a (realistic) change in economic model can make appreciative materialism possible at a bigger scale and profitable at a macro level. A brand like Patagonia already makes a profit thanks to appreciative materialism. Its mission is to "build the best product, cause no unnecessary harm, use business to inspire and implement solutions to the environmental crisis" (retrieved from Patagonia.com on 1 December 2019). It offers durable clothes and promotes reuse, recycling, reduced consumption, and making repairs to its products. In the fashion industry, some ethical fashion brands have decided to keep their collection longer, produce in limited quantity on the basis of the availability of local resources, and not discount their products during the year. Many of these brands have also chosen to lower their margins so that, in the end, a pair of shoes produced locally and ethically does not cost more than many of the sneakers sold by well-advertised sports brands (that have much larger margins), for instance.

An interesting case to study is the success of the Italian Slow Food Movement, which has become a worldwide phenomenon-what Husemann and Eckhardt (2019) call consumer deceleration. The slow movement includes slow money, slow cities, slow tourism, slow fashion, and even slow technology (Clancy 2018; Hallnäs and Redström 2001; Honoré 2004; Ozdamar Ertekin and Atik 2015; Tasch 2008). Instead of being an anti-movement that frontally faces brands and mainstream consumers engaged in fast living, it is conceived as a hedonistic lifestyle - a right to pleasure (Sassatelli and Davolio 2010) — that operates in 
the marketplace to better re-educate consumers and gradually change the market rules. The slow movement is an interesting case for appreciative materialism for at least two reasons. First, the movement has been supported by public institutions, as was the case with the Cittaslow slow city movement that mayors implemented in Italy. In this respect, we agree with Burroughs et al. (2013) and Nepomuceno and Laroche (2015) that policymakers have a role to play in the development of more sustainable forms of consumption (in our case, appreciative materialism), especially when appreciative materialists do not feel like missionaries, as we have seen in our study. Second, the slow movement is partly successful because it does not negate but affirms pleasure by being conceived as a hedonistic lifestyle. This is probably a critical point in a consumer society that often relies on desire (Belk et al. 2003), while messages to protect our planet tend to limit desire by associating reduced consumption with constraints and sacrifice. In line with Black, Shaw, and Trebeck (2017), we argue that appreciative materialism and, more generally, resistance to accumulation can be practiced profitably if doing so triggers desire-for instance, by being promoted as a form of alternative hedonism (Soper 2008), especially at a time when consumers are also stressed workers. This also echoes, in our opinion, the necessity to take a more Deleuzian approach to desire as creative and revolutionary (Deleuze and Guattari 1980): Appreciative materialism and other sustainable forms of consumption can only be widely accepted if they trigger desire, not sacrifice.

\section{Conclusion}

Alexander and Ussher (2012, p. 67) remind us that "few people (and no governments, in the developed world, at least) are prepared to accept that attaining an ecologically sustainable global economy requires the global consumer class to consume less." In our study of appreciative materialism in the context of Polish simplifiers, we have shown that our participants attach great importance to their possessions (visible, in particular, through caring) and partly take account of the (low) quantity and (high) quality of their possessions to evaluate happiness and success. While these findings should be nuanced due to possible social, historical, and cultural differences that we have highlighted above, they nevertheless remain important because they point to the relevance of appreciative materialism as an expression of materialism that does not oppose, on the one hand, materialism and consumption and, on the other hand, anti-materialism and anti-consumption. Appreciative materialism differs from low levels of accumulative materialism, and materialism scales should therefore be updated to include such alternate and evolving expressions of materialism. To this end, we have suggested including caring items related to proximity, attachment, commitment, and respect, which correspond to appreciative materialism.

As Serres and Latour (1990/1995, p. 81) declare in the quotation at the top of this paper, "an idea opposed to another is always the same idea." While we must consume less, appreciative materialism helps us not only to rethink but also to assume and accept our relations to materiality. As soon as materialism is no longer demonized because it can also contribute to reduced consumption by being appreciative, all actors in the capitalist economies will be able to start thinking of an ecologically sustainable future: one that does not pit itself against an economic system that is, for now, barely replaceable but by and large improvable.

Acknowledgements The authors acknowledge the helpful input of the associate editor and reviewers, the social and marketing lab at TBS Business School, André Crous, as well as the participants of the 2018 ACR conference in Dallas.

Funding This research was supported by a grant from the National Science Centre in Poland (No. 2014/13/N/HS6/02686) awarded to Justyna Kramarczyk.

\section{Compliance with Ethical Standards}

Conflict of interest The authors declare that they have no conflict of interest.

Human Rights and Ethical Approval This research was conducted in accordance with the ethical standards of the institutional and/or national research committee and with the 1964 Helsinki Declaration and its later amendments or comparable ethical standards.

Informed Consent Informed consent was obtained from all individual participants included in the published ethnography.

Open Access This article is licensed under a Creative Commons Attribution 4.0 International License, which permits use, sharing, adaptation, distribution and reproduction in any medium or format, as long as you give appropriate credit to the original author(s) and the source, provide a link to the Creative Commons licence, and indicate if changes were made. The images or other third party material in this article are included in the article's Creative Commons licence, unless indicated otherwise in a credit line to the material. If material is not included in the article's Creative Commons licence and your intended use is not permitted by statutory regulation or exceeds the permitted use, you will need to obtain permission directly from the copyright holder. To view a copy of this licence, visit http://creativecommons.org/licenses/by/4.0/.

\section{References}

Ahuvia, A. C., \& Wong, N. Y. (2002). Personality and values based materialism: Their relationship and origins. Journal of Consumer Psychology, 12(4), 389-402.

Albinsson, P. A., Wolf, M., \& Kopf, D. A. (2010). Anti-consumption in east Germany: Consumer resistance to hyperconsumption. Journal of Consumer Behaviour, 9(1), 412-425. 
Alexander, S. (2011). The voluntary simplicity movement: Reimagining the good life beyond consumer culture. International Journal of Environmental, Cultural, Economic, and Social Sustainability, 7(3), 133-150.

Alexander, S., \& Ussher, S. (2012). The voluntary simplicity movement: A multi-national survey analysis in theoretical context. Journal of Consumer Culture, 12(1), 66-86.

Appadurai, A. (1986). The social life of things: Commodities in cultural perspective. Cambridge: Cambridge University Press.

Appadurai, A. (2015). Mediants, materiality, normativity. Public Culture, 27(2), 221-237.

Babin, B. J., Darden, W. R., \& Griffin, M. (1994). Work and/or fun: Measuring hedonic and utilitarian shopping value. Journal of Consumer Research, 20(March), 644-656.

Ballantine, P. W., \& Creery, S. (2010). The consumption and disposition behaviour of voluntary simplifiers. Journal of Consumer Behaviour, 9(1), 45-56.

Bandak, A. (2017). Opulence and simplicity: The question of tension in Syrian catholicism. In K. Norget, V. Napolitano, \& M. Mayblin (Eds.), The anthropology of catholicism: A reader (pp. 155-169). Oakland, CA: University of California Press.

Banister, E. N. \& Hogg, M. K. (2004). Negative symbolic consumption and consumers' drive for self-esteem: The case of the fashion industry. European Journal of Marketing, 38(7), 850-868

Bardhi, F., \& Eckhardt, G. M. (2012). Access-based consumption: The case of car sharing. Journal of Consumer Research, 39(December), 881-898.

Bekin, C., Carrigan, M., \& Szmigin, I. (2005). Defying marketing sovereignty: Voluntary simplicity at new consumption communities. Qualitative Market Research: An International Journal, 8(4), 413-429.

Belk, R. W. (1984). Three scales to measure constructs related to materialism: Reliability, validity, and relationships to measures of happiness. In T. C. Kinnear (Ed.), NA-Advances in consumer research (Vol. 11, pp. 291-297). Provo, UT: Association for Consumer Research.

Belk, R. W. (1985). Materialism: Trait aspects of living in the material world. Journal of Consumer Research, 12(December), 265-280.

Belk, R. W. (1988). Possessions and the extended self. Journal of Consumer Research, 15(September), 139-168.

Belk, R. W. (2010). Sharing. Journal of Consumer Research, 36(February), 715-734.

Belk, R. W., Ger, G., \& Askegaard, S. (2003). The fire of desire: A multisited inquiry into consumer passion. Journal of Consumer Research, 30(December), 326-351.

Belk, R. W., Sherry Jr, J. F., \& Wallendorf, M. (1988). A naturalistic inquiry into buyer and seller behavior at a swap meet. Journal of Consumer Research, 14(March), 449-470.

Belk, R. W., Wallendorf, M., \& Sherry Jr, J. F. (1989). The sacred and the profane in consumer behavior: Theodicy on the Odyssey. Journal of Consumer Research, 16(June), 1-38.

Benson, M. H. (2019). New materialism: An ontology for the anthropocene. Natural Resources Journal, 59(Summer), 251-280.

Black, I. R., Shaw, D., \& Trebeck, K. (2017). A policy agenda for changing our relationship with consumption. Journal of Cleaner Production, 154(June), 12-15.

Bourdieu, P. (1972/1977). Outline of a theory of practice. Cambridge: Cambridge University Press.

Bourdieu, P. (1979/1984). Distinction: A social critique of the judgement of taste. New York: Routledge.

Brislin, R. W. (1970). Back-translation for cross-cultural research. Journal of Cross-Cultural Psychology, 1(3), 185-216.

Brown, K. W., \& Kasser, T. (2005). Are psychological and ecological well-being compatible? The role of values, mindfulness, and lifestyle. Social Indicators Research?, 74(2), 349-368.
Burroughs, J. E., \& Rindfleisch, A. (2002). Materialism and wellbeing: A conflicting values perspective. Journal of Consumer Research, 29(December), 348-370.

Burroughs, J. E., Chaplin, L. N., Pandelaere, M., Norton, M. I., Ordabayeva, N., Gunz, A., et al. (2013). Using motivation theory to develop a transformative consumer research agenda for reducing materialism in society. Journal of Public Policy \& Marketing, 32(Spring), 18-31.

Canniford, R., \& Shankar, A. (2013). Purifying practices: How consumers assemble romantic experiences of nature. Journal of Consumer Research, 39(February), 1051-1069.

Cherrier, H. (2009). Anti-consumption discourses and consumer-resistant identities. Journal of Business Research, 62(2), 181-190.

Cherrier, H., \& Murray, J. B. (2007). Reflexive dispossession and the self: Constructing a processual theory of identity. Consumption, Markets and Culture, 10(1), 1-29.

Chowdhury, R. (2018). Religiosity and voluntary simplicity: The mediating role of spiritual well-being. Journal of Business Ethics, 152(2), 149-174.

Clancy, M. (2018). Slow tourism, food and cities: Pace and the search for the "Good Life". New York: Routledge.

Craig-Lees, M., \& Hill, C. (2002). Understanding voluntary simplifiers. Psychology \& Marketing, 19(2), 187-210.

Czapiński, J., \& Panek, T. (2015). Social diagnosis 2015: Objective and subjective quality of life in Poland. Contemporary Economics, 9(4), 1-545.

Davidson, A., Habibi, M. R., \& Laroche, M. (2018). Materialism and the sharing economy: A cross-cultural study of American and Indian consumers. Journal of Business Research, 82, 364-372.

Davidson, A., Nepomuceno, M. V., \& Laroche, M. (2019). Shame on you: When materialism leads to purchase intentions toward counterfeit products. Journal of Business Ethics, 155, 479-494.

Deleuze, G. \& Guattari, F. (1980/1987). A thousand plateaus: Capitalism and schizophrenia. Minneapolis: University of Minnesota.

Descola, P. (2005/2013). Beyond nature and culture. Chicago: The University of Chicago.

Dolbec, P.-Y., \& Fischer, E. (2015). Refashioning a field? Connected Consumers and institutional dynamics in markets. Journal of Consumer Research, 41(April), 1447-1468.

Dolphijn, R., \& van der Tuin, I. (2012). New materialism: Interviews and cartographies. London: Open Humanities Press.

Douglas, M. \& Isherwood, B. (1979/1996). The world of goods: Towards an anthropology of consumption, New York: Routledge.

Dunlap, R. E., \& Mertig, A. G. (1997). Global environmental concern: An anomaly for postmaterialism. Social Science Quarterly, 78(1), 21-29.

Eberts, M. W. (1998). The Roman Catholic church and democracy in Poland. Europe-Asia Studies, 50(5), 817-842.

Elgin, D., \& Mitchell, A. (1977). Voluntary simplicity. The Co-Evolution Quarterly, 3(1), 4-19.

Elgin, D. (1981). Voluntary simplicity: Toward a way of life that is outwardly simple, inwardly rich. New York: Morrow.

Epp, A. M., \& Price, L. L. (2010). The storied life of singularized objects: Forces of agency and network transformation. Journal of Consumer Research, 36(February), 820-837.

Etzioni, A. (1998). Voluntary simplicity: Characterization, select psychological implications, and societal consequences. Journal of Economic Psychology, 19(5), 619-643.

Fromm, E. (2013/1978). To Have or To Be. New York: Bloomsbury.

Ger, G., \& Belk, R. W. (1996). Cross-cultural differences in materialism. Journal of Economic Psychology, 17(February), 55-77.

Ger, G., Belk, R. W., \& Lascu, D.-N. (1993). The development of consumer desire in marketizing and developing economies: The cases of romania and Turkey. In L. McAlister \& M. L. Rothschild (Eds.), NA-Advances in consumer research (Vol. 20, pp. 102-107). Provo, UT: Association for Consumer Research. 
Glaser, B. G., \& Strauss, A. L. (1967). The discovery of grounded theory: Strategies for qualitative research. Chicago, IL: Aldine.

Gopaldas, A. (2008). Anti-consumption: Now on sale. In A. Y. Lee \& D. Soman (Eds.), NA-Advances in consumer research (Vol. 35, pp. 730-731). Duluth MN: Association for Consumer Research.

Gregg, R. (1936/1974). Simplicity. Visva-Bharati Quarterly, reprinted in Manas, 27(36), 1-13.

Gregoire, Y., Tripp, T. M., \& Legoux, R. (2009). When customer love turns into lasting hate: The effects of relationship strength and time on customer revenge and avoidance. Journal of Marketing, 73(November), 18-32.

Guha, R., \& Alier, J. M. (1997). Varieties of environmentalism: Essays north and south. London: Earthscan Publications.

Hallnäs, L., \& Redström, J. (2001). Slow technology—designing for reflection. Personal and Ubiquitous Computing, 5(August), 201-212.

Harman, G. (2011). The quadruple object. Alresfold: Zero Books.

Hoffman, D. L., \& Novak, T. P. (2018). Consumer and object experience in the internet of things: An assemblage theory approach. Journal of Consumer Research, 44(April), 1178-1204.

Hogg, M. K. (1998). Anti-constellations: Exploring the impact of negation on consumption. Journal of Marketing Management, 14(1-3), 133-158.

Honoré, C. (2004). In praise of slow: How a worldwide movement is challenging the cult of speed. London, UK: Orion.

Humphreys, A. (2010). Megamarketing: The creation of markets as a social process. Journal of Marketing, 74(March), 1-19.

Huneke, M. E. (2005). The face of the un-consumer: An empirical examination of the practice of voluntary simplicity in the United States. Psychology \& Marketing, 22(7), 527-550.

Husemann, K. C., \& Eckhardt, G. M. (2019). Consumer deceleration. Journal of Consumer Research, 45(April), 1142-1163.

Inglehart, R. (1977). The silent revolution: Changing values and political styles among western publics. Princeton: Princeton University Press.

Iyer, R., \& Muncy, J. A. (2009). Purpose and object of anti-consumption. Journal of Business Research, 62, 160-168.

Jackson, T. (2005). Live better by consuming less? Is there a 'Double Dividend' in sustainable consumption? Journal of Industrial Ecology, 9(1-2), 19-36.

Johnson, S., \& Loveman, G. W. (1995). Starting over: Poland after communism. Harvard Business Review, 73(2), 44-57.

Kala, L., Galčanová, L., \& Pelikán, P. (2017). Narratives and practices of voluntary simplicity in the Czech post-socialist context. Sociologicky Casopis-Czech Sociological Review, 53(6), 833-855.

Karabati, S., \& Cemalcilar, Z. (2010). Values, materialism, and wellbeing: A study with Turkish University students. Journal of Economic Psychology, 31(August), 624-633.

Kasser, T., Ryan, R. M., Zax, M., \& Sameroff, A. J. (1995). The relations of material and social environments to late adolescents' materialistic and prosocial values. Developmental Psychology, 31(6), 907-914.

Kasser, T. (2003). The High Price of Materialism. Cambridge, MA: The MIT Press.

Kilbourne, W., McDonagh, P., \& Prothero, A. (1997). Sustainable consumption and the quality of life: A macromarketing challenge to the dominant social paradigm. Journal of Macromarketing, 17(1), 4-24.

Kilbourne, W., \& Pickett, G. (2008). How materialism affects environmental beliefs, concern, and environmentally responsible behavior. Journal of Business Research, 61(September), 885-893.

Kisielewska, Z. (2013) Minimalizm-Mniej, Czyli Więcej. Focus, December 26.

Kissmann, U. T., \& van Loon, J. (2019). Discussing new materialism: Methodological implications for the study of materialities. Wiesbaden: Springer VS.
Klein, N. (1999). No Logo. London: Flamingo.

Klich, A., \& Siewiorek, R. (2013). Miej Mniej, Gdy Chcesz Więcej. Wyborcza, February 15.

Kopytoff, I. (1986). The cultural biography of things: Commoditization as process. In A. Appadurai (Ed.), The social life of things: Commodities in cultural perspective (pp. 64-91). Cambridge: Cambridge University Press.

Kornai, J. (1992). The socialist system: The political economy of communism. Princeton, NJ: Princeton University Press.

Kotler, P. (2011). Reinventing marketing to manage the environmental imperative. Journal of Marketing, 75(July), 132-135.

Kozinets, R. V. (2002). Can consumers escape the market? Emancipatory illuminations from burning man. Journal of Consumer Research, 29(June), 20-38.

Kozinets, R. V., \& Handelman, J. M. (2004). Adversaries of consumption: Consumer movements, activism, and ideology. Journal of Consumer Research, 31(December), 691-704.

Kucuk, S. U. (2016). Brand hate: Navigating consumer negativity in the digital world. Basingstoke, UK: Palgrave Macmillan.

Latour, B. (2005). Reassembling the social: An introduction to actornetwork theory. Oxford: Oxford University Press.

Lee, M. S. W., Motion, J., \& Conroy, D. (2009). Anti-consumption and brand avoidance. Journal of Business Research, 62(February), 169-180.

Leonard-Barton, D. (1981). Voluntary simplicity lifestyles and energy conservation. Journal of Consumer Research, 8(December), 243-252.

Levy, S. J. (1959). Symbols for sale. Harvard Business Review, 17(JulyAugust), 117-124.

Lofman, B. (1993). Consumers in rapid transition: The polish experience. In L. McAlister \& M. L. Rothschild (Eds.), NA-Advances in Consumer Research (Vol. 20, pp. 18-22). Provo, UT: Association for Consumer Research.

Long-Chuan, L. U., \& Chia-Ju, L. U. (2010). Moral Philosophy, Materialism, and Consumer Ethics: An Exploratory Study in Indonesia. Journal of Business Ethics, 94, 193-210.

Maniates, M. (2002). Search of consumptive resistance: The voluntary simplicity movement. In T. In Princen, M. Maniates, \& K. Conca (Eds.), Confronting consumption (pp. 199-235). Cambridge, MA: MIT.

Martin, D. M., \& Schouten, J. W. (2014). Consumption-driven market emergence. Journal of Consumer Research, 40(February), $855-870$.

McCracken, G. (1986). Culture and consumption: A theoretical account of the structure and movement of the cultural meaning of consumer goods. Journal of Consumer Research, 13(June), 71-84.

Meillassoux, Q. (2007). Speculative realism: Presentation by quentin meillassoux. Collapse, 3, 408-449.

Mick, D. G. (1996). Are studies of dark side variables confounded by socially desirable responding? The case of materialism. Journal of Consumer Research, 19(September), 106-199.

Miller, D. (1987). Material culture and mass consumption. Oxford: Blackwell.

Moisander, J., \& Pesonen, S. (2002). Narratives of sustainable ways of living: Constructing the self and the other as a green consumer. Management Decision, 40(4), 329-342.

Morren, M., \& Grinstein, A. (2016). Explaining environmental behavior across borders: A meta-analysis. Journal of Environmental Psychology, 47(September), 91-106.

Muncy, J. A., \& Eastman, J. K. (1998). Materialism and consumer ethics: An exploratory study. Journal of Business Ethics, 17(2), 137-145.

Nepomuceno, M. V., \& Laroche, M. (2015). The impact of materialism and anti-consumption lifestyles on personal debt and account balances. Journal of Business Research, 68(3), 654-664. 
Nepomuceno, M. V., \& Laroche, M. (2017). When materialists intend to resist consumption: The moderating role of self-control and longterm orientation. Journal of Business Ethics, 143(3), 467-483.

Ozdamar Ertekin, Z., \& Atik, D. (2015). Sustainable markets motivating factors, barriers, and remedies for mobilization of slow fashion. Journal of Macromarketing, 35(1), 53-69.

Pandelaere, M. (2016). Materialism and well-being: The role of consumption. Current Opinion in Psychology, 10(August), 33-38.

Parker, K., Horowitz, J., Igielnik, R., Oliphant, B., \& Brown, A. (2017). America's complex relationship with guns: An in-depth look at the attitudes and experiences of U.S. Adults. Report of the Pew Research Center.

Pędziwiatr, K. (2015). Church and state relations in Poland with special focus on the radio station mary. In G. Simons \& D. Westerlund (Eds.), Religion, politics and nation-building in the post-communist countries (pp. 163-178). London: Ashgate.

Pretty, J., Ball, A., Benton, T., Guivant, J., Lee, D. R., Orr, D., et al. (2007). Introduction. In J. Pretty, A. Ball, T. Benton, J. Guivant, D. R. Lee, D. Orr, M. Pfeffer, \& H. Ward (Eds.), The Sage handbook on environment and society (pp. 1-32). London: Sage.

Richins, M. L. (2004). The material values scale: Measurement properties and development of a short form. Journal of Consumer Research, 31(June), 209-219.

Richins, M. L., \& Rudmin, F. W. (1994). Materialism and economic psychology. Journal of Economic Psychology, 15(June), 217-231.

Richins, M. L., \& Dawson, S. (1992). A consumer values orientation for materialism and its measurement: Scale development and validation. Journal of Consumer Research, 19(December), 303-316.

Roberts, B. W., \& Mroczek, D. (2008). Personality trait change in adulthood. Current Directions in Psychological Science, 17(1), 31-35.

Roux, D., \& Belk, R. W. (2019). The body as (another) place: Producing embodied heterotopias through tattooing. Journal of Consumer Research, 46(October), 483-507.

Rudmin, F. W., \& Kilbourne, W. E. (1996). The meaning and morality of voluntary simplicity: History and hypotheses on deliberately denied materialism. In R. W. Belk, N. Dholakia, \& A. Venkatesh (Eds.), Consumption and marketing: Macro dimensions (pp. 166-215). Cincinnati, OH: South-Western College Publishing.

Santora, M., \& Berendt, J. (2019). Mixing politics and piety, a conservative priest seeks to shape Poland's future. The New York Times, September 21. Available at: https://www.nytim es.com/2019/09/21/world/europe/poland-elections-tadeusz-rydzy k.html

Sassatelli, R., \& Davolio, F. (2010). Consumption, pleasure and politics: Slow food and the politico-aesthetic problematization of food. Journal of Consumer Culture, 10(2), 202-232.

Scaraboto, D., Ferreira, M. C., \& Chung-Moya, E. (2016). Materials matter: An exploration of the curatorial practices of consumers as collectors. In N. Özçaglar-Toulouse, D. Rinallo, \& R. W. Belk (Eds.), Consumer culture theory: Research in consumer behavior (pp. 219-243). Emerald: Bingley.

Schlosberg, D., \& Coles, R. (2016). The new environmentalism of everyday life: Sustainability, material flows, and movements. Contemporary Political Theory, 15(2), 160-181.

Scott, K., Martin, D. M., \& Schouten, J. W. (2014). Marketing and the new materialism. Journal of Macromarketing, 34(3), 282-290.

Scott, R., Cayla, J., \& Cova, B. (2017). Selling pain to the saturated self. Journal of Consumer Research, 44(June), 22-43.

Serres, M., \& Latour, B. (1990/1995). Conversations on Science, Culture, and Time. Ann Harbor, MI: University of Michigan.

Sexty, R. W. (1998). Teaching business ethics in transitional economies: Avoiding ethical missionary. Journal of Business Ethics, $17,1311-1317$.

Shama, A. (1981). Coping with staglation: Voluntary simplicity. Journal of Marketing, 45(Summer), 120-134.
Shaw, D., \& Moraes, C. (2009). Voluntary simplicity: An exploration of market interactions. International Journal of Consumer Studies, 33(March), 215-223.

Shaw, D., \& Newholm, T. (2002). Voluntary simplicity and the ethics of consumption. Psychology \& Marketing, 19(2), 167-185.

Shaw, D., McMaster, R., \& Newholm, T. (2015). Care and commitment in ethical consumption: An exploration of the 'Attitude-Behavior Gap'. Journal of Business Ethics, 136(2), 251-265.

Shrum, L. J., Wong, N., Arif, F., Chugani, S. K., Gunz, A., Lowrey, T. M., et al. (2013). Reconceptualizing materialism as identity goal pursuits: Functions, processes, and consequences. Journal of Business Research, 66(August), 1179-1185.

Sirgy, M. J. (1998). Materialism and quality of life. Social Indicators Research, 43(3), 227-260.

Soper, K. (2008). Alternative hedonism, cultural theory and the role of aesthetic revisioning. Cultural Studies, 22(5), 567-597.

Spiggle, S. (1994). Analysis and interpretation of qualitative data in consumer research. Journal of Consumer Research, 21(December), 491-503.

Strizhakova, Y., \& Coulter, R. A. (2013). The "green" side of materialism in emerging BRIC and developed markets: The moderating role of global cultural identity. International Journal of Research in Marketing, 30(1), 69-82.

Sutyrin, S. F., \& Vorobieva, I. V. (2017). Russian consumer behavior. In search of a balance between National Uniqueness and Western Mainstream. In M. A. Marinov (Ed.), Research handbook of marketing in emerging economies (pp. 222-240). Cheltenham, UK: Edward Elgar.

Tasch, W. (2008). Inquiries into the nature of slow money: Investing as if food, farms, and fertility mattered. White River Junction, VT: Chelsea Green.

Tobacyk, J., Babin, B. J., Attaway, J. S., Socha, S., Shows, D., \& James, K. (2011). Materialism through the eyes of Polish and American Consumers. Journal of Business Research, 64(9), 944-950.

Tokarczuk, O. (2019). The Tender Narrator, Nobel Lecture. Available at https://www.nobelprize.org/prizes/literature/2018/tokar czuk/104871-lecture-english/.

Tronto, J. C. (1993). Moral boundaries: A political argument for an ethic of care. New York: Routledge.

Urien, B., \& Kilbourne, W. (2008). On the role of materialism in the relationship between death anxiety and quality of life. In A. Y. Lee \& D. Soman (Eds.), NA-Advances in consumer research (Vol. 35, pp. 409-415). MN: Association for Consumer Research, Duluth.

Veenis, M. (1999). Consumption in East Germany: The seduction and betrayal of things. Journal of Material Culture, 4(1), 79-112.

Verdery, K. (1996). What was socialism, and what comes next? Princeton, NJ: Princeton University Press.

Wilk, R. R. (1997). A critique of desire: Distaste and dislike in consumer behavior. Consumption, Markets and Culture, 1(2), 175-196.

Witkowski, T. H. (2010). A brief history of frugality discourses in the United States. Consumption, Markets and Culture, 13(September), 235-258.

Zalewska, J., \& Cobel-Tokarska, M. (2016). Rationalization of pleasure and emotions: The analysis of the blogs of Polish minimalists. Polish Sociological Review, 196(4), 495-512.

Zaltman, G. (1997). Rethinking market research: Putting people back in. Journal of Marketing Research, 34(November), 424-437.

Zavestoski, S. (2002). The social-psychological bases of anti-consumption attitudes. Psychology \& Marketing, 19(2), 149-165.

Publisher's Note Springer Nature remains neutral with regard to jurisdictional claims in published maps and institutional affiliations. 